\title{
Financial Analysis Report of Easyjet Airline Co., Ltd vs. US Airways Group
}

\author{
Yuan Zhang \\ Xijing University, Xi'an Shaanxi, 710123, China
}

\begin{abstract}
Keywords: Financial strategy analysis, Financial profitability analysis, Financial statements, Corporate performance.
\end{abstract}

\begin{abstract}
Nowadays accompanying with economic globalization and the development of information technology, it becomes increasing critical on financial analysis to the multinational companies listed. The efficient capital markets provide probabilities to the financial analysis on both financial and non-financial information of companies themselves and their competitors. Financial statements are an important source of information for analyzing corporate performance by whatever inside analysts or outside stakeholders. Meanwhile by comparing related information between the company and its competitors, it drives the company to operate better in practice..
\end{abstract}

\section{Introduction}

In this financial analysis report, it focuses on an airline company listed in the UK with the name of Easyjet Airline Co., Ltd (Easyjet airline) because it is worldwide welcome for the low-cost air travel, it is a typical targeted company for our analysis based on an UK company listed and its sales revenue stably increase in the past five years. At the same time, it selectes a similar industry company named US Airways Group (US airways) for the purpose of comparing in some cases. Which conducts our analysis on three stages, firstly, reviewing business strategies of both companies, which includes correspond core competencies, industry background as well as their strategic issues implied. And then it takes accounting analysis to assess the quality of financial information of both companies. Finally, it analyses profitability using the decomposition framework of key financial ratios. The overall financial analysis relies on the information of the past five-year time horizon from 2007 to 2011 (spotlighted in recent 2 years), whatever financial information or non-financial information implied in this report.

\section{Strategic review}

Easyjet airline is one of the few pan-European low-cost carriers in the European, and it is becoming popular in the world. Observing the strategic of Easyjet airline, it includes several aspects, as it would like to be the leading of the Europe's preferred short-haul airline company, so in order to reach this target, its core competencies are going to make air-travel easy and affordable, to deliver point-to-point low fares with operational efficiency and friendly service for customers, to use low cost product enablers and so forth. Thus, the aim of this company is to generate the safely, passional, and simply travel agency in the world. In accordance with the annual report and accounts 2011, Carolyn McCall, Easyjet airline CEO, said that owing to the staffs' hard working, Easyjet airline has delicate financial performance through the years, and also it claimed that Easyjet airline has robust operations which mean that the strong operational performance drives the customer's satisfaction.

Meanwhile, by going through all the annual reports in the past five years, it shows the long-term business strategies of Easyjet airline are to become the best low fares airline in the world, to build the 
Europe's No.1 air transport network and having low cost, and to maximize operating margins. For analysing the company more wisely; it does a lot of data research which are financial ratios from the financial statements to guarantee whether the targeted firm obtaining or not. While, focusing on Easyjet airline financial strategies from the annual reports, the strategy and business models depend on the following financial strengths: the low cost and financial strong and highly efficient. According to the 2008 Annual report, the Jeff Carr of the group finance director concluded some key performance indicators to present the results influenced by some factors, such as the fuel prices, GB Airways acquisition and the strengthening euro exchange rate. Total revenue increased and traced the passenger number rose. Meanwhile underlying cost per seat fell. So in the competitive and regulatory environment, more competitors are indulged. Especially, the US airways group airline company, which is different from the Easyjet airline airline company, US airways is not dependent; it is a membership of the US Star Alliance. So it owns highly competitive, like price competition, market competitive of the route system, basis of scheduling (frequency and flight times) and so forth, according to the US airways annual report 2011. Then it shows obviously, the Easyjet airline has more powerful competition than the US airwayss. Using the original balance sheet and income statement to reformulate new ones; it aims to detect the driver of ROCE (return on common equity) and growth in preparation for forecasting and valuation. Some ratios calculated from the reformulated statements, and these ratios would become into the comprehensive analysis of profitability and growth.

\section{Financial accounting quality analysis}

It is well known that different accounting policies and treatments play different roles on the preparation of financial statement. As it is stated in annual reports of Easyjet airline, some key items are highlighted such as, statement of compliance is in accordance with international financial reporting standards (IFRS) and its related interpretation which provides unified criterion for our comparison by cross-sectional analysis; Basis of preparation is based on the historic cost convention except for certain financial assets and liabilities above which are measured at fair value, and all accounts are prepared consistently; Significant judgements, estimates and critical accounting policies, such as Goodwill and landing rights, Aircraft maintenance provision and tax policy. After viewing all notes of the accounts and related figures disclosed, it could be valued that accounts of Easyjet airline are recorded truly and fairly, applied critical accounting policies, judgements and estimates are appropriate and legal with it is stated in its annual reports, meanwhile the valuation could be suitable to US airways in the same way.

\section{Common-size analysis between Easyjet airline and US airways}

In order to analyse the corporate performance of targeted company, it needs to establish a benchmark for cross-sectional analysis and trend analysis. Considering the differences on sub-ledger accounts, booking currency and report time-period (Easyjet airline is reported on 30 Sep of financial year however US airways on 31 Dec of fiscal year) between two selected firms. Then consolidated and reformulaed financial statements by a normal template in sterling, which regards different report time-period as the same time-period for comparison.

While all financial statements of two airline companies in the past five years come from Thomson one banker system. As the financial statements are not prepared well in original statements, so it should reformulated. Thus the most important criterion is to justify the character of non-interest bearing or interest bearing between all accounts. As it is stated by Penman S.H. (2007, P.300), and the purpose of reformulating financial statement is to reveal the drivers of return on common equity (ROCE) and corresponding growth in order to preparing for corporate forecasting and performance valuation. Operating assets and liabilities are involved items with the form of assets or obligations in selling goods or providing services. The dimension of operating activities and financial activities is not suitable to every business which means different industries have different classification, so it 
should be tailored based on the business industry. Normally it is a good method to classify them by putting the priority of financial items in non-financial industries since they are easily identified. As it shows in Easyjet airline, financial assets only include the account of Short-term Investments, and financial liabilities cover Short-term Debt \& Current Portion of Long-term Debt, Long-term Debt and Deferred stock, the remaining accounts in the balance sheet belong to operating assets and liabilities. Then in accordance with this classification to the business activities, it results in net financial expense listed in the income statement from financial activities, as it is stated at interest expense less interest income; the leftover accounts in the income statement would be regarded as operating income and expense in practice. The financial analysis in this report is based on the formulated balance sheet and income statement provided as appendices.

\section{Cross-sectional analysis}

It shows the analysis of the balance sheet between two companies. We firstly notice that Cash account weights around $40 \%$ of net operating assets in the past two years in both firms. Secondly; the account of Property, Plant and Equipment in both companies are over 80\%, however the ratio of US airways is much higher than the ratio of targeted firm; it indicates that both firms depend on Fixed Assets investment due to their character of special industry. Thirdly we note that the account of Long-term Debt weights about 45\% of Easyjet airline while over 87 per cent of its competitor which means light liability bearing to Easyjet airline.

Also we can note that both companies have around 80 per cent operating cost over revenue which indicates relatively low profitability in the airline industry because the operating cost is increasing, such as fuels, labour cost, depreciation expense of invested FA. Due to multi-operating scopes of US airways including not only passengers' service, but also express service and luggage service; its yearly revenue appears much higher than Easyjet airline that is simply focusing on passengers' revenue. The consequent operating income is affected by low rate of gross margin, only around 5\% between two firms.

\section{Trend analysis (Time-series analysis)}

After viewing the Trend analysis in the balance sheet of Easyjet airline, it shows obviously that we should spotlight on the account of Cash; Property, Plant and Equipment and Current Long-term Portion of Debt as well as Long-term Debt because they are stably increasing in the past two years, furthermore they weight majority of amount over total assets or sum of liabilities and stockholders' equity. Operating assets of Cash and Property, Plant and Equipment weight $162 \%$ and $230 \%$ of total assets respectively over the base of 2007 which also guarantee the importance between both accounts as above cross-sectional analysis. Financial obligations of Short-term Debt and Long-term Debt describe airline industry relying on borrowings and loans to raise funding for operation purpose; accompanying with corporate business expanding, the amount of two accounts are growing to 383\% and $239 \%$ of the base in 2007 respectively.

We also should focus on the amount of net operating income (NOI) and net financial expense (NFE) in table 4, that the general trend of NOI is gradually rising. The ratio of NOI grows up from $£ 139.80$ million of 2007 to £238.72 million of 2011, increasing to $171 \%$ of the base of 2007 . Meanwhile we can note that a good outcome results from the corresponding NFE that it is decreasing in recent three years from $£ 17.88$ million of 2009 to $£ 13.72$ million of 2011 due to the shortage of interest-bearing period, because we can deduce from the increase of the account of Current portion of long-term debt. Considering the complex of tax policy and the limitation of available information in both firms, we ignore the related influence to our analysis.

\section{Financial profitability analysis}


Financial profitability analysis is a good way for management planning, strategy analysis, and decision making, as well as valuation. In this report looking at the airline companies, the profitability would be impacted by the capacity utilization and good full-service. So database from the reformulated financial statements has a link between the quality and the profitability. Obviously the return on common equity (ROCE) could examine investor and company reaction. Meanwhile, the ROCE and its components illustrate the size of the adjusted return, which has the close relationship between the earnings and revenues unexpected surprises. So our results are significant for the financial statement users who would like to invest or manage the company effectively. Focusing on the traditional DuPont model, ROCE is composed by the net profit margin (NPM), total asset turnover (ATO) and financial leverage (LEV): ROCE= NPMATOLEV, according to the Eli Amir \& Itay Kama (2005). But relying on the Stephen H. Penman (2010), ROCE is determined by three levels. Separately the first-level is to distinguish the financial and operating activities and the financial leverage; the second level focus on the drivers of operating profitability. And then, the third-level affects the profit margin rates and asset turnovers. For example, the ROCE results are collected from two different types of companies, which are Easyjet and US Airways financial statements. About five years as follows:

\begin{tabular}{ccccccc}
\hline & & 2007 & 2008 & 2009 & 2010 & 2011 \\
\hline \multirow{2}{*}{ ROCE } & Easyjet & 0.1322 & 0.0651 & 0.0545 & 0.0808 & 0.1320 \\
\hline & US Airways & 0.5907 & 6.2919 & 0.9325 & 9.3566 & 0.7356
\end{tabular}

It can be seen that US Airways company has higher ROCE rate than the Easyjet company. Which means Easyjet corporation owns a formidable rival. And also, it owns stable profit than the US Airways firm. The performance of the Easyjet is more wisely. Especially focusing on the 2007 and 2008, the ROCE began to decrease. Through looking at the annual report of Easyjet in 2007 and 2008, there are some issues of the risk bore upon the financial performance. Which is the fuel price risk management policy to manipulate the increased fuel price. Unfortunately there exists a hedge about maximum $80 \%$ of estimated exposures in 30 September 2007, according to the Annual Report in 2007. So the ROCE decreased from 2007 to 2008.

\section{The first-level breakdown}

While in order to recognise the performance of the Easyjet firm well, it can be analysed from operating activities and financing activities and the effect of leverage. And comparing with US Airways Corporation, the profitability of the Easyjet would be clarified and revealed well. Hence it can analyse from two leverages. One is the financial leverage, and the other is operating leverage. Some data from the financial statements show below:

\begin{tabular}{ccccccc}
\hline & & 2007 & 2008 & 2009 & 2010 & 2011 \\
\hline \multirow{2}{*}{ FLEV } & Easyjet & 0.270 & 0.235 & 0.586 & 0.599 & 0.538 \\
\hline & US Airways & 2.0306 & -7.8733 & -12.7493 & 52.3810 & 30.4400
\end{tabular}

Financial leverage (FLEV) =net financial obligation (NFO) / common stockholder's equity(CSE) (1)

ROCE (return on common equity) =RNOA (return on net operating assets) +( FLEV (RNOA-NBC (net borrowing cost))). (2)

From the table, it shows clearly that the number of FLEV in Easyjet company increases from 27\% to $53.8 \%$ from the 2007 to 2011 . All the figures are positive, so it reflects financial assets are less than financial liabilities. FLEV is positive. But the FLEV of the US Airways Company is opposite to the Easyjet. Thus, financial assets are greater than financial liabilities. Finally the figure of FLEV affects the ROCE. "It indicates that a median RNOA of $10 \%$ is much closer to what expect as a return to business operations" (Doron Nissim \& Stephen H. Penman 2003). So the business strategies of the Easyjet, during the 2007 to 2011, would be more effectively in financial performance. From the 
equation (2), it shows the financial leverage controlling the FLEV and the spread between RNOA and the borrowing rate. Here a positive spread may reduce the ROCE. Which means if the financial assets earn less than operating assets, ROCE would be lower than RNOA. The following charts reflect the change obvious.

And besides focusing on the operating liability leverage, which affects the operating profitability. The RNOA reveals the operating income related to net operating assets. So operating liability leverage (OLLEV) would be more important for the company to evaluate the performance. The formulation shows as follows:

Operating liability leverage $(\mathrm{OLLEV})=$ Operating liabilities $(\mathrm{OL}) /$ Net operating assets (NOA)

While the figure of the OLLEV hides in the RNOA, but the total change of RNOA displays changing of OLLEV and operating abilities. Looking at the Easyjet company's strategies, the delivery point-to-point low fares and the minimal cost product enablers reflect stable ROCE, which evaluates the company's efficient strategies.

\section{The second-level breakdown of ROCE}

One part of the DuPont analysis can be seen the second-level breakdown of ROCE analysis. Thus, the driver of the ROCE includes RNOA and leverage. In this second-level analysis, RNOA=PM ATO. Noting that Easyjet has stable PM values from 2007 to 2011. As the standard analysis, PM analyses from the equation: $\mathrm{PM}=\mathrm{OI} / \mathrm{Sales}$ (Profit Margin). It displayed that how much the company owns the earnings compared to sales. Meawhile, the higher the figure, the better the company's business ratios, according to the Michael Eikenberry \& Jonathan Lord \& Kelly Campbell \& Diana Duran (2007). And comparing with the two charts, Easyjet has better service than US Airways. While looking at the ATO ratio, it depends on the NOA to generate sales. Which can be equated as ATO = Sales/NOA. If the company owns high turnover, it would attract competition. But the values of this ratio opposites the PM. The data, from the following tables, shows the change of the two ratios, which are more clearly.

\begin{tabular}{ccccccc}
\hline & & 2007 & 2008 & 2009 & 2010 & 2011 \\
\hline PM & Easyjet & 0.0778 & 0.0305 & 0.0334 & 0.0459 & 0.0692 \\
\hline & US Airways & 0.0450 & -0.1683 & 0.0128 & 0.0687 & 0.0291 \\
\hline \multirow{2}{*}{ ATO } & Easyjet & 1.2278 & 1.4971 & 1.2861 & 1.2387 & 1.3166 \\
\hline & US Airways & 5.3405 & 5.0195 & 4.0489 & 4.1578 & 4.3021 \\
\hline
\end{tabular}

\section{The third-level breakdown}

In order to operate the company's operating well, the analyst would be more deeply analyse the PM and ATO. And it breaks the profit margin into two components. Which is PM = Sales PM + Other items PM and ATO divided into the liabilities and assets. Then they are just regarded as the tool to gain more information. Finally, the analyst and manager may know how to alter the company's business and financial strategies. Thus the profitability may be controlled immediately.

\section{Conclusions}

To sum up, through analysing the Easyjet and US Airways's strategies, accounting quality, accounting policies, judgement, estimates and probability, it displays the Easyjet company will have a potential developing in the future. But it does not say there is no risks or channelling. Combining the accounting quality, strategy and probability analysing together, the analysis will become more accurate. And focusing on the Easyjet's long-term target, which is reducing the costs, and become the No.1 Europ airline company, and looking at financial ratios, from 2007 to 2011, Easyjet performed well. Especially, the operating performance, which was reflected in improvements in customer 
satisfaction. Then it leads into more passengers preferring to choice the Easyjet at first. Forward booking for the first half of the 2013 financial year, with around 45\% of winter seats now booked, it dependents on the Annual Report of 2012. Whilst there exists potential for unexpected events to occur, but the boards of Easyjets is confident to confront.

\section{References}

[1] Doron Nissim \& Stephen H. Penman (2003), Financial Statement Analysis of Leverage and How It Informs About Profitability and Price-to-Book Ratios, Review of Accounting Studies, 9,531-560

[2] Eli Amir \& Itay Kama (2005), Market Reaction to ROCE and ROCE Components, SSRN-id623161

[3] Michael Eikenberry \& Jonathan Lord \& Kelly Campbell \& Diana Duran (2007), Business Analysis and Equity Valuation, Chevron Corporation Reasearch Report.

[4] Penman S.H. (2007/2010), Financial statement analysis and security valuation (McGraw Hill). 3rd ed. McGraw-Hill International Edition, pp.300, 303 345.

[5] Basic data output system: Thomson one banker.

[6] Report of the europe by easyjet annual report (2012/2011/10/09/08/07), Available from: http://2012annualreport.easyjet.com/performance-risk/financial-review.aspx

[7] http://2008annualreport.easyjet.com/performance-risk/financial-review.aspx

[8] http://2007annualreport.easyjet.com/performance-risk/financial-review.aspx

[9] http;//2010annualreport.easyjet.com/performance-risk/financial-review.aspx

[10]http://2009annualreport.easyjet.com/performance-risk/financial-review.aspx

[11]2007-2009 US airways annual report: http://www.usairways.com/EN-US/ABOUTUS/INVESTORRELATIONS/FINANCIALREPOR T.HTML

[12]http://en.wikipedia.org/wiki/EasyJet

[13]http://en.wikipedia.org/wiki/US_Airways 